\title{
Training New Research Trainers: an Open Science and Medical Education Innovative Experience
}

Angela Theresa Zuffo Yabrude ( $\nabla$ yabrudea@gmail.com )

Universidade Regional de Blumenau https://orcid.org/0000-0002-2779-7334

\section{Letícia Nunes Campos}

Universidade de Pernambuco https://orcid.org/0000-0002-8064-5698

\section{Samantha Sartore Duque Estrada Medeiros}

Pontifícia Universidade Católica de Campinas https://orcid.org/0000-0002-6538-4784

\section{Clarissa Garcia Custódio}

Pontifícia Universidade Católica de São Paulo https://orcid.org/0000-0002-6153-3850

Richardson Chaves de Abreu

Universidade Federal de Maranhão - Pinheiro campus https://orcid.org/0000-0003-1964-6269

Sarah Laís Silva de Freitas

Universidade Federal de Campina Grande https://orcid.org/0000-0002-8232-4898

Moises da Costa Cunha

Universidade Anhanguera https://orcid.org/0000-0002-9666-6581

Hillary Sayuri Ramires Hoshino

Universidade de Taubaté https://orcid.org/0000-0001-8360-1650

Barbara de Almeida Sena da Silva

Universidade de Tiradentes https://orcid.org/0000-0002-6980-0183

Lucas Loiola Ponte Albuquerque Ribeiro

Universidade de Fortaleza https://orcid.org/0000-0002-7620-6393

Cristina Pires Camargo

Universidade de São Paulo https://orcid.org/0000-0002-3134-0003

\section{Research Article}

Keywords: Capacity Building; Competency-Based Education; Research Personnel; Students, Medical

Posted Date: June 7th, 2021

DOl: https://doi.org/10.21203/rs.3.rs-598174/v1

License: (c) (1) This work is licensed under a Creative Commons Attribution 4.0 International License. Read Full License 



\section{Training New Research Trainers: an Open Science and Medical Education Innovative Experience}

Angela Theresa Zuffo Yabrude. School of Medicine, Universidade Regional de

Blumenau, Santa Catarina, Brazil. ORCID: 0000-0002-2779-7334

Letícia Nunes Campos. School of Medicine, Universidade de Pernambuco, Pernambuco, Brazil. ORCID: 0000-0002-8064-5698

Samantha Sartore Duque Estrada Medeiros. School of Medicine, Pontifícia Universidade Católica de Campinas, São Paulo, Brazil. ORCID: 0000-0002-6538-4784 Clarissa Garcia Custódio. Faculty of Medicine, Pontifícia Universidade Católica de São

Paulo, São Paulo, Brazil. ORCID: 0000-0002-6153-3850.

Richardson Chaves de Abreu. School of Medicine, Universidade Federal de Maranhão Pinheiro campus, Maranhão, Brazil. ORCID: 0000-0003-1964-6269

Sarah Laís Silva de Freitas. School of Medicine, Universidade Federal de Campina Grande, Paraíba, Brazil. ORCID: 0000-0002-8232-4898

Moises da Costa Cunha. School of Medicine, Universidade Anhanguera, Mato Grosso do Sul, Brazil. ORCID: 0000-0002-9666-6581

Hillary Sayuri Ramires Hoshino. School of Medicine, Universidade de Taubaté, São Paulo, Brazil. ORCID: 0000-0001-8360-1650

Barbara de Almeida Sena da Silva. School of Medicine, Universidade de Tiradentes, Alagoas, Brazil. ORCID: 0000-0002-6980-0183

Lucas Loiola Ponte Albuquerque Ribeiro. School of Medicine, Universidade de Fortaleza, Ceará, Brazil. ORCID: 0000-0002-7620-6393

Cristina Pires Camargo. MD, PhD e Microsurgery and plastic surgery laboratory, Universidade de São Paulo, São Paulo, Brazil. ORCID: 0000-0002-3134-0003 Institution: International Federation of Medical Students Association of Brazil (IFMSA Brazil). Avenida Paulista, no 1765, São Paulo, São Paulo, Brazil

Corresponding author: Angela Theresa Zuffo Yabrude, Arno Lueders Street, 299, Blumenau, Santa Catarina, Brazil, +55 47 991561028, yabrudea@gmail.com

Funding support: no funding support exists.

Word counts of the text: 2327. Word counts of the abstract: 249 .

Number of figures and tables: 3 . 


\section{Abstract}

Introduction: Open science is a valuable path to boost the global potential of scientific research by removing barriers for producing, disseminating, and putting science into practice, with the spirit of collaboration, inclusivity and focusing on communities' rising demands. Open science principles instigate the management of scientific knowledge and the enhancement of abilities such as research, project management, team-building skills, and numerous others, which are essential for medical practice according to international recommendations, although still underexplored by medical schools. Methods: Open science, peer education, student leadership and developing of scientific skills were cornerstones to promote the Training New Research Trainers, the first edition of a national Brazilian student-led online workshop aiming to capacitate medical students in such targeted competencies and abilities through active teaching and learning methodologies. Results: Despite the challenges of online format, as impairment in some dynamics and assessment methods, it improved the access to the event from all Brazilian regions, totaling 409 submissions. Thus, it was necessary to have a previous selection of participants and adjustments in the workshop to assist twice the expected attendants. Discussion: Training New Research Trainers surpassed the national distribution inequalities of research opportunities and resources; mirrored open science bases in terms of access, education and methodology; and showed to be a promising opportunity for students to be protagonists of their learning process and to contribute to future changes in their reality, especially regarding the public health landscape. Improvements and consolidation of the workshop protocol and its expansion through national and international partnerships are the following goals.

Keywords: Capacity Building; Competency-Based Education; Research Personnel; Students, Medical. 


\section{Introduction}

Open Science consists of removing barriers in sharing productions, resources, methods, or tools in the research process, opening the different stages of the research cycle [1]. Most importantly, open science carries the logic that scientific knowledge comes from social collaboration, so its outputs are a public good that should be accessible at no cost [1]. Open science's essentials are to promote transparency, reproducibility, and replication in medical studies [2]. Through this sharing process, a collaborative and transparent environment in research is established, facilitating the search for factual evidence [3].

Furthermore, open science addresses the need to accept diverse understandings of knowledge. Such a challenging proposal implies that different parties should be considered in scientific production, including the medical students [4]. Given this group's exposure to societal and patients' needs, integrating research with medical education becomes of paramount importance [5]. In alignment with open science principles in which subjects can produce, share, and build on the knowledge, it is essential to consider strategies to develop scientific skills among medical students.

Peer education, among the teaching possibilities, describes interventions in which educators and educated people have a common characteristic. Moreover, peer education activities promote inclusive and integrative approaches compared to traditional teaching methods such as expositive lectures [6,7]. This issue associated with the limited access to program and research opportunities during the graduation course hinders medical students from learning and acquiring scientific skills [7].

In this sense, initiatives that value open science promotion through peer education and student leadership are necessary to ensure progress. Based on these 
cornerstones, the International Federation of Medical Students Associations of Brazil (IFMSA Brazil) hosted the first edition of the Training New Research Trainers (TNRT) as an alternative to permit medical students to develop research competencies and abilities. This study is the first description of a research skills workshop entirely led by Brazilian medical students to the best of our knowledge. Therefore, this article aims to report a pilot experience from the TNRT workshop as an alternative strategy to foster science accessibility and education.

\section{Methods}

The TNRT planning happened in November 2019. The workshop was conceived to give participants autonomy on how to use, share, govern, and manage their scientific knowledge towards populational demands. The TNRT planning involved national officers from different IFMSA Brazil frameworks, including capacity building, research exchanges, medical education, and publications \& research. Due to the COVID-19 pandemic, the TNRT moved online and took place in September 2020, having its first edition at the national level. The TNRT occurred on two subsequent weekends, using the GoToMeeting platform. Also, the IFMSA directors chose eight trainers to facilitate the sessions as shown in Figure 1.

The TNRT addressed the following topics: capacitate participants in characterizing study designs, train participants in formulating a research question by the PICOT method, make attendees comprehend issues on research bioethics and manage bias, enable attendees to understand types 1 and 2 errors, and apply them into scientific hypothesis tests, train the participants in articles' critical appraisal, make attendees acquainted with the peer-reviewing and publishing process, teach participants in searching on different databases, develop research skills, correlating with medical education, human rights, and global health, comprehend the concept of Open Science, 
its policies and applicability within IFMSA's priorities and development of communication, project management, and team-building skills within the trainees. Targeted competencies and abilities per training session are further described in Tables 1 and 2 in light of existing frameworks [8].

To warrant the workshop feature on capacity building, the TNRT demanded active teaching and learning methodologies application, putting participants in a protagonist position in the learning process. In the workshop, trainers made use of the following methods: mind mapping [9], group presentation [10], problem-based learning [11-13], small working group [14,15], game-based learning [16], role-playing [17], learning by doing [18,19], team-based learning [20-22], scavenger hunts [23], brainstorming [24,25], online discussion board [26]. Applied methods per training session are outlined in Tables 1 and 2.

Table 1. Active Learning Methodologies and Educational Outcomes in the Training New Research Trainers Workshop

\begin{tabular}{|c|c|c|}
\hline $\begin{array}{l}\text { TNRT Training } \\
\text { Sessions }\end{array}$ & Applied methodologies & Developed competencies and abilities \\
\hline $\begin{array}{l}\text { Presentation } \\
\text { Skills }\end{array}$ & $\begin{array}{l}\text { Mind mapping; Group } \\
\text { presentation }\end{array}$ & $\begin{array}{l}\text { Competencies: Language and communication skills } \\
\text { Abilities: } \\
\text { 1) Express ideas clearly, meaningfully, and articulately } \\
\text { 2) Deliver effective presentation using oral and artistic } \\
\text { skills } \\
\text { 3) Adapt communication depending on the audience }\end{array}$ \\
\hline Study Designs & $\begin{array}{l}\text { Problem-based learning } \\
\text { and Small Working } \\
\text { Group; Game-based } \\
\text { learning }\end{array}$ & $\begin{array}{l}\text { Competency: research methodology } \\
\text { Ability: Understand the statistical, epidemiological, and } \\
\text { operational elements of distinct study designs }\end{array}$ \\
\hline $\begin{array}{l}\text { Critical Appraisal } \\
\text { and Peer Review }\end{array}$ & $\begin{array}{l}\begin{array}{l}\text { Small working group; } \\
\text { Learning by doing; } \\
\text { Game-based learning }\end{array} \\
\begin{array}{l}\text { Brainstorming; } \\
\text { working group }\end{array} \\
\begin{array}{l}\text { Role-playing; Problem } \\
\text { based learning; Small } \\
\text { working group }\end{array}\end{array}$ & $\begin{array}{l}\text { Competency: Disseminating research findings } \\
\text { Abilities: } \\
\text { 1) Understand the importance of and how to access, } \\
\text { critique, and synthesize literature } \\
\text { 2) Be aware of the differing requirements and formats } \\
\text { of journals' submission and reviewing processes } \\
\text { 3) Be aware of the concept of plagiarism and } \\
\text { requirements for citations of others' work } \\
\text { 4) Understand the publication process steps and } \\
\text { barriers } \\
\text { 5) Contribute to and write a publication or report } \\
\text { 6) Write and submit abstracts to conferences or journals } \\
\text { 7) Assist in the preparation of and deliver oral or poster } \\
\text { presentations at scientific meetings }\end{array}$ \\
\hline
\end{tabular}




\begin{tabular}{|c|c|c|}
\hline $\begin{array}{l}\text { Literature Search } \\
\text { Bias, Statistical } \\
\text { Error, and } \\
\text { Scientific } \\
\text { Hypothesis }\end{array}$ & $\begin{array}{l}\begin{array}{l}\text { Problem-based learning; } \\
\text { Role playing; } \\
\text { Game-based learning }\end{array} \\
\text { Scavenger Hunts } \\
\text { Team-based learning; } \\
\text { problem-based learning; } \\
\text { game-based learning }\end{array}$ & $\begin{array}{l}\text { Competencies: Health-related knowledge and research } \\
\text { methodology } \\
\text { Abilities: } \\
\text { 1) Recognize the knowledge gaps and suggest a } \\
\text { reasonable and practicable research question, } \\
\text { associating with the most coherent study design and } \\
\text { measures } \\
\text { 2) Understand how to access scientific literature } \\
\text { properly } \\
\text { 3) Extract data from database and conduct data } \\
\text { analyses using statistical software packages } \\
\text { 4) Identify whether conclusions drawn from analyses of } \\
\text { data are valid and based on the material provided }\end{array}$ \\
\hline $\begin{array}{l}\text { Human Rights } \\
\text { Research }\end{array}$ & $\begin{array}{lr}\text { Game-based } & \text { learning; } \\
\text { Small Working } & \text { Group; } \\
\text { Role-Playing } & \\
& \\
\text { Role-playing; } & \text { small } \\
\text { working } & \text { groups; } \\
\text { problem-based learning }\end{array}$ & $\begin{array}{l}\text { Competency: Ethics and human subject protection } \\
\text { Abilities: } \\
\text { 1) Understand the history and evolution of ethical } \\
\text { theory principles and the key documents related to } \\
\text { human subjects in research } \\
\text { 2) Take a balanced view of the likely harms and } \\
\text { benefits of a research project and to vulnerable } \\
\text { communities } \\
\text { 3) Understand the need for ethical approval to be } \\
\text { obtained before research activities progress } \\
\text { 4) Ensure that payments or compensations for subjects } \\
\text { for taking part do not constitute coercion or undue } \\
\text { influence } \\
\text { 5) Demonstrate high integrity, and consistently respect } \\
\text { and ensure confidentiality and privacy of research } \\
\text { participants } \\
\text { 6) Contribute to the informed consent process, ensuring } \\
\text { that the participant fully understands the research }\end{array}$ \\
\hline
\end{tabular}

Table 2. Active Learning Methodologies and Educational Outcomes in the Training New Research Trainers Workshop (continuation)

\begin{tabular}{|c|c|c|}
\hline $\begin{array}{ll}\text { TNRT } & \text { Training } \\
\text { Sessions } & \\
\end{array}$ & Applied methodologies & Developed competencies and abilities \\
\hline $\begin{array}{l}\text { Project } \\
\text { Management }\end{array}$ & Team-based learning & $\begin{array}{l}\text { Competency: Project management and Human } \\
\text { Resources } \\
\text { Abilities: } \\
\text { 1) Oversee study and site management, including } \\
\text { managing multiple sites/laboratories and ensuring } \\
\text { consistency } \\
\text { 2) Plan schedules, timelines, and processes within } \\
\text { study } \\
\text { 3) Coordinate or manage teams } \\
\text { 4) Understand project management processes and } \\
\text { tools } \\
\text { 5) Recruit and select team, plan, and coordinate their } \\
\text { training as required } \\
\text { 6) Ensure that individuals have received and } \\
\text { understood instructions and protocols to conduct their } \\
\text { work safely }\end{array}$ \\
\hline Training Skills & Online discussion board & $\begin{array}{l}\text { Competency: Creating or delivering training } \\
\text { Abilities: } \\
\text { 1) Deliver effective training in front of groups } \\
\text { 2) Produce materials such as manuals or } \\
\text { presentations }\end{array}$ \\
\hline
\end{tabular}




\begin{tabular}{|c|c|c|}
\hline & & $\begin{array}{l}\text { 3) Determine the appropriate subject topic, assess } \\
\text { audience responsiveness to training, repeat and } \\
\text { paraphrase source material to produce an effective } \\
\text { training session }\end{array}$ \\
\hline $\begin{array}{l}\text { Medical Education } \\
\text { Research }\end{array}$ & Group presentation & $\begin{array}{l}\text { Competency: interpersonal skills } \\
\text { Abilities: } \\
\text { 1) Enable articulation of the views of those who find } \\
\text { it difficult to express themselves } \\
\text { 2) Listen effectively and encourage open } \\
\text { communication } \\
\text { 3) Negotiation and conflict management skills } \\
\text { 4) Effective networking skills, can build alliances and } \\
\text { strategic partnerships } \\
\text { 5) Be aware of the challenges in medical education } \\
\text { research 6) Understand the principles of } \\
\text { evidence-based medicine }\end{array}$ \\
\hline $\begin{array}{l}\text { Global } \\
\text { Research }\end{array}$ & $\begin{array}{lr}\text { Role-playing; } & \text { small } \\
\text { working } & \text { groups; } \\
\text { problem-based learning }\end{array}$ & $\begin{array}{l}\text { Competency: Health-related knowledge } \\
\text { Abilities: } \\
\text { 1) Comprehend the differences between public } \\
\text { health, global health, international health, plenary } \\
\text { health, and one health in terms of subjects, scope, and } \\
\text { targeted population } \\
\text { 2) Understand the multiple health determinants and } \\
\text { their impact on patients } \\
\text { 3) Be enlightened on health system disparities } \\
\text { 4) Solve problems concerning global health under the } \\
\text { perspective of the sustainable development goals }\end{array}$ \\
\hline Open Science & Online discussion board & $\begin{array}{l}\text { Competency: Governance and organizational context } \\
\text { Abilities: } \\
\text { 1) Comprehend the characteristics of open science } \\
\text { 2) Apply open access, open data, open methodology, } \\
\text { open-source, open peer review, open educational } \\
\text { resources' principles on daily situations faced by } \\
\text { medical students and early-career researchers }\end{array}$ \\
\hline
\end{tabular}

\section{Results}

The online workshop yielded more than 400 submissions throughout the country, making it necessary to build a Small Working Group (SWG) for selecting the participants, who were evaluated by a double blinded written interview about motivation and previous experience regarding research. This IFMSA Brazil SWG selected 50 undergraduate medical students, twice as previously expected, from the five geographical regions in Brazil (North, Northeast, Midwest, Southeast, South) and enrolled students from the first to the sixth year of the undergraduate course. The representation of the distribution of the participants and the number of higher education 
institutions, according to the city, is represented in Figure 1. The participants were divided into two groups $(\mathrm{n}=25)$.

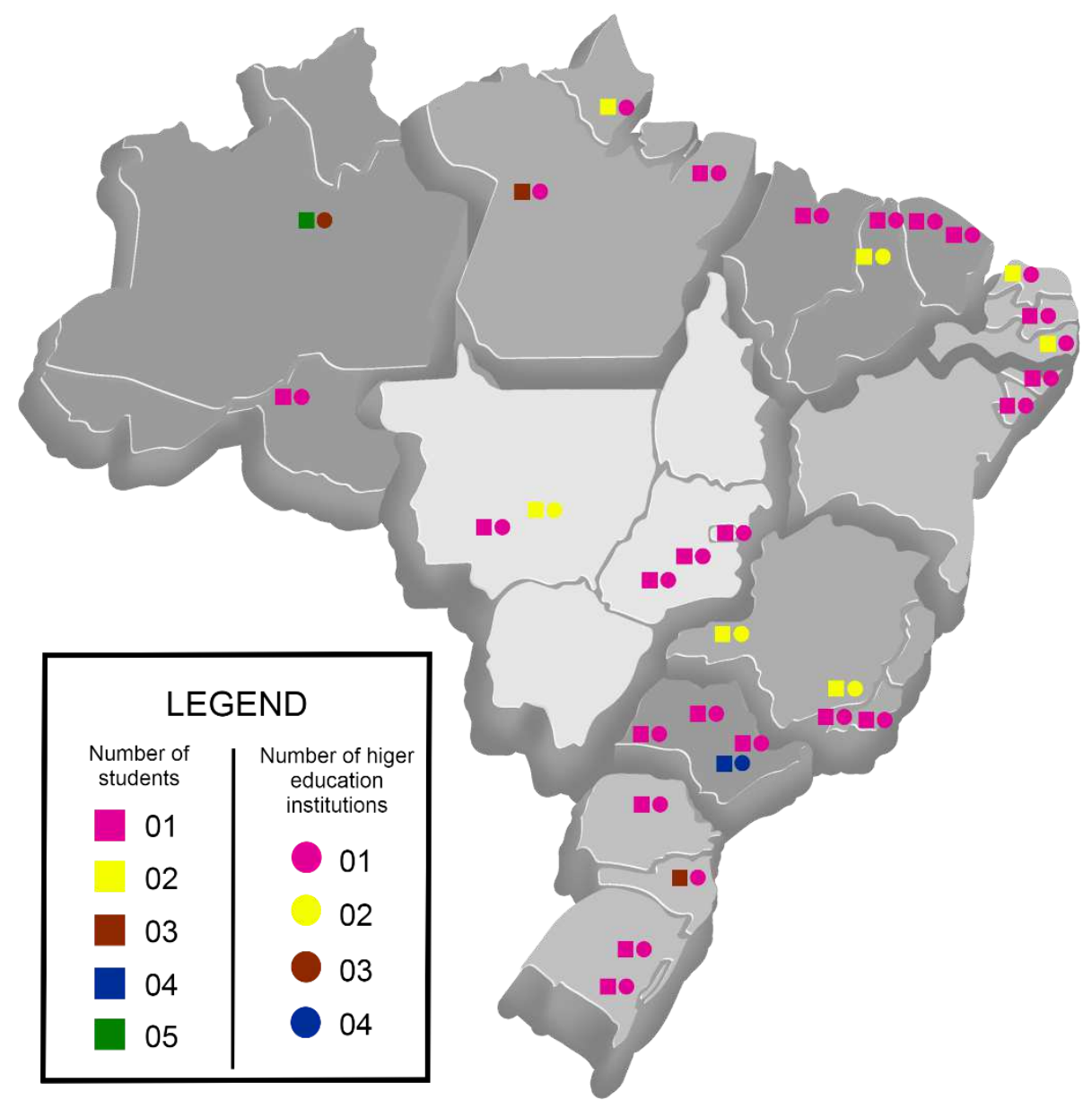

The event lasted for five days, having a total workload of 25 hours. The TNRT course offered 17 training sessions, and no study materials were made available to the participants before beginning the workshop. Each training started with a presentation of the session's agenda, followed by a 20 to 30 minutes' theoretical explanation and 60 minutes of practical activities to develop targeted competencies and abilities. Finally, trainers collected feedback from participants in a method of their choice. Moreover, trainers could perform ice-breakers and energizers as an engagement strategy throughout the training. 
Using active methodologies allowed participants to have meaningful involvement with the agenda topics. During the event, participants seemed more captivated by small working group dynamics. However, trainers had difficulty assessing whether a participant progressed in some skills such as oral presentation or teamwork due to the remote adaptation. From the trainers' point of view, despite the impairment of the non-verbal communication, attendees' overall participation was satisfactory considering the virtual workshop setting.

Conversely, going virtual had its challenges. In spite of the great variety of used active learning techniques, online platforms hamper the application of methodologies that would suit the face-to-face format. These alterations may impact the achievement of the expected learning outcomes for the training sessions. Another concern was to keep the energy and engagement of participants even with the extended workload. Lastly, although trainers had independence in choosing the feedback technique to evaluate their training, the assessment methods' lack of uniformity might interfere with understanding the sessions' outcomes.

\section{Discussion}

Our report described the TNRT 2020 edition, consisting of the first description of an entirely Brazilian student-led workshop focused on encouraging and democratizing research skills education. Through a virtual and active learning approach, the TNRT promoted an experience that involved students from different parts of the country and situated openness by breaking context, power, and inequality boundaries into scientific research.

Open science was the cornerstone of our initiative since themes such as open access, data, and educational resources were pervasive and mirrored on the workshop online platforms' usage, its gratuity, and application of active teaching on scientific 
skills. This rationale also extends to the TNRT conception, which resembles an open science response to rising demands. When creating an open-source product, a researcher goes through an iterative cycle by 1: identifying a problem or need, 2: posing a preliminary solution to this problem, 3: appealing to the general public, 4: receiving contributions unrestrictedly from the community, and 5: releasing the product and restarting the cycle when necessary [27]. The TNRT was designed after noticing medical students' difficulty in learning research. Given this background, our workshop followed this collaborative workflow, under the perspective that it received inputs from different stakeholders, including IFMSA Brazil national officers, trainers, and attendees.

Our report also provides an example of how remote teaching encourages and democratizes research. Initiatives like the TNRT may bring several benefits to the national research structure marked by significant regional disparities. The workshop adaptation to an online format was relevant in financial, equitable, and educational terms. By adopting a virtual design, the workshop became free of charge and travel costs. Because of this increased accessibility, the TNRT attracted trainees from the five Brazilian regions, regardless of socioeconomic status, gender, race, and other factors. Such a modification permitted the attendance of more trainees as firstly speculated, having an overall of 50 participants, which came from 32 cities in Brazil (Figure 1).

According to Clarivate Analytics' assessment in Brazil, clinical research seems the most productive field in which several specialties have a high citation impact. Nevertheless, the majority of publications concentrate in the Southeast region [28]. Likewise, this inequitable pattern is perceived by the country's institutional review boards' distribution (IRBs). As reported by the National Commission on Research Ethics or Comissão Nacional de Ética em Pesquisa (CONEP), until February 2021, Brazil counted with 850 IRBs, 70 located in the North, 179 in the Northeast, 69 in the 
Midwest, 382 in the Southeast, and 150 in the South region [29]. Since IRBs are responsible for the ethical evaluation of research projects and play an instructional and protective role for the scientific community and society, their unequal distribution compromises research and innovation expansion on national territory. Provided this context, efforts in decentralizing national research involve setting mechanisms to optimize research personnel training. Hence, activities such as the TNRT are essential to educating junior researchers with distinct socioeconomic and geographic aspects. Consequently, the odds of developing significant local projects may increase, corroborating a context-centered approach to promoting science.

A high point of our experience was applying active learning for research education purposes. Such methodologies allow the development of relevant competencies, abilities, and attitudes for healthcare and research settings. Besides being an effective strategy to improve students' attention, motivation, and professional skills [30,31], active teaching can boost students' self-criticism, team building, leadership, and advocacy capacities [32,33]. This method allows the consolidation of a peer feedback-based environment, promoting the sharing of experiences in research education [34] and vital communication skills for physicians' practice [35].

Among the adopted active-learning models, it is clear that peer education played a vital role in our workshop. Such methodology contributes to awakening students' interest in challenging tasks, enhancing scholarly achievement, and fostering prosocial behavior, features that, ultimately, are relevant for the development of student leadership [36]. During the TNRT, attendees participated in peer-led discussions that strengthened student protagonism. Furthermore, peer education is crucial to identify knowledge and abilities gaps according to the addressed public [37]. For example, whereas skills as literature search seemed unchallenging to a technological generation, 
participants demonstrated constraints when appraising articles. These nuances were acknowledged owing to peer education, which helped trainers identifying major areas to tackle with attendees.

Besides these aspects, the TNRT recalls the intimate relationship between medical routine and scientific development, which directly interferes within the public health landscape. According to the Royal College of Physicians and Surgeons of Canada, doctors must contribute to advance health care, evidence-based medicine, and shared decision-making. This expertise can be achieved by identifying gaps of knowledge, formulating critical hypotheses, creating, and disseminating research findings, and translating them to applicable medical practice [38].

Similarly, the Future Doctors Programs proposed by the National Health System in the United Kingdom (UK) determines that each physician is a scientist and a scholar and needs to weigh up the scientific evidence relevant to their patient's condition and recommend the best treatment [39]. Moreover, UK doctors should demonstrate understanding of the research process and ethics, participate in collaborative research projects, honesty, and integrity within the scientific field [39]. In parallel, the Brazilian Curricula Guidelines for the Medical Graduation Course encourages medical doctors to apply scientific reasoning to daily clinical practice. Furthermore, the guidelines pose the following abilities as intrinsic to the medical profession: formulating research questions and hypotheses, searching data, executing critical analysis of sources, methods, and results. In general, by evolving on such skills, the medical doctor would favor scientific and technological development, relating those to meet patients' and public health demands [40].

Although these specific medical graduation policies offer guidance to develop critical scientific maturity amidst future physicians, previous studies exhibit the need to 
provide more educational opportunities for research [41-43]. Correspondingly, our workshop represents an extracurricular activity to foster research teaching and enable students to detect health system needs from an in-depth perspective. These activities increase the critical analysis by focusing on global health, open science, and medical education. Such a context associated with active methodologies application played a role in making attendees develop interventions focused on the national health system in a scientific and responsible format. Thus, by strengthening investigations centered on health users, the development of effective and socially accountable health practices becomes possible [44].

The TNRT had some limitations. First, this paper reports a pilot edition of a student-led workshop whose protocol is still under development to consolidate future versions of the initiative. Therefore, assessing the workshop educational outcomes in the light of established guidelines and a more significant sample is required. Second, despite the increased effort in applying active learning methods, online platforms present some restrictions that allow their full utilization, interfering with the attendees' interaction. Third, as trainers used multiple and non-uniform feedback assessments, interpretation of overall outcomes was hampered. Fourth, our workshop restricted its target public to be medical students. Because the event provided an innovative way to disseminate knowledge and capacitate research skills, expanding the participation from other health-related undergraduates is another point of improvement.

\section{Conclusion}

Although essential for medical practice, managing scientific knowledge through producing, searching, appraising, and putting research into practice is still underexplored by medical schools. To ponder the advances of science to the individuality of medical care demands is fundamental to settle the best context and 
ethical assistance, and graduation should be the time to develop such abilities. The TNRT was an opportunity for social collaboration to build research competencies and make students protagonists of open science. Additionally, the workshop demonstrates the feasibility of promoting a more equal, accessible, and decentralized opportunity provision in research education. Because the TNRT was online, this increases the likelihood of its reproducibility by other organizations. On the other hand, methodological limitations should be noticed since the interpretation of results was impaired owing to the virtual environment. Besides, even though the workshop focused only on medical students, it can be adapted to other courses. To propagate TNRT workshops both virtually and in-person via national and international partnerships are the following goals to expand the dissemination of knowledge and practical abilities proposed, including access and education on research, open science, and evidence-based medicine to form leaders for changes in their realities.

Acknowledgments: We would like to thank the board and all members of IFMSA Brazil who somehow supported and contributed to the I Training New Research Trainers.

Authors Contribution: A.T.Z.Y, L.N.C contributed to the conceptualization and design of the study. A.T.Z.Y., L.N.C., S.S.D.E.M, C.G.C, R.C.A., S.L.S.F., M.C.C., H.S.R.H., B.A.S.S., L.L.P.A.R., C.P.C. contributed to data collection, analysis, interpretation and writing the original draft. S.S.D.E.M and R.C.A were responsible for data visualization. Reviewing and supervision was made of C.P.C. All authors agreed with the final version of the manuscript, and are held accountable of all aspects of this study.

Declaration of Interests: the authors declare no conflicts of interest exist. 


\section{References:}

1. Fuente GB de la. What is Open Science? Introduction [Internet]. FOSTER Open Science. Retrived 15 Feb 2021. Available from: https://www.fosteropenscience.eu/content/what-open-science-introduction

2. Figueiredo Filho D, Lins R, Domingos A, Janz N, Silva L. Seven Reasons Why: A User's Guide to Transparency and Reproducibility. Braz Polit Sci Rev. 2019;13(2):e0001.

3. Moher D, Naudet F, Cristea IA, Miedema F, Ioannidis JPA, Goodman SN. Assessing scientists for hiring, promotion, and tenure. PLOS Biol. 2018 Mar 29;16(3):e2004089.

4. Hall BL, Tandon R. Decolonization of knowledge, epistemicide, participatory research and higher education. Res All. 2017 Jan 1;1(1):6-19.

5. Ianni PA, Samuels EM, Eakin BL, Perorazio TE, Ellingrod VL. Assessments of Research Competencies for Clinical Investigators: A Systematic Review. Eval Health Prof. 2019 Dec 23. Available from: https://pubmed.ncbi.nlm.nih.gov/31867997/

6. Shiner M. Defining peer education. J Adolesc. 1999 Aug;22(4):555-66.

7. Guimarães JA. A pesquisa médica e biomédica no Brasil: comparações com o desempenho científico brasileiro e mundial. Ciênc Saúde Coletiva. 2004 Jun;9(2):303-27.

8. Research Competencies. Global Health Training Centre [Internet]. Retrived 26 Mar 2021. Available from: https:/globalhealthtrainingcentre.tghn.org/pds/core-competency-framework/

9. Rosciano A. The effectiveness of mind mapping as an active learning strategy among associate degree nursing students. Teach Learn Nurs. 2015 Apr;10(2):93-9.

10. Gilkar S, Lone S, Lone R. Introduction of active learning method in learning physiology by MBBS students. Int J Appl Basic Med Res. 2016;6(3):186.

11. Ibrahim M, AlShahrani A, Abdalla M, Abubaker I, Mohamed M. The Effectiveness of Problem-based Learning in Acquisition of Knowledge, Soft Skills During Basic and Preclinical Sciences: Medical Students' Points of View. Acta Inform Medica. 2018;26(2):119.

12. Wang J, Xu Y, Liu X, Xiong W, Xie J, Zhao J. Assessing the effectiveness of problem-based learning in physical diagnostics education in China: a meta-analysis. Sci Rep. 2016 Dec;6(1):36279.

13. Imanieh MH, Dehghani SM, Sobhani AR, Haghighat M. Evaluation of problem-based learning in medical students' education. J Adv Med Educ Prof. 2014 Jan;2(1):1-5.

14. Wilson KJ, Brickman P, Brame CJ. Group Work. CBE-Life Sci Educ. 2018 Mar;17(1):fe1.

15. Schmutz JB, Meier LL, Manser T. How effective is teamwork really? The relationship between teamwork and performance in healthcare teams: a systematic review and meta-analysis. BMJ Open. 2019 Sep;9(9):e028280. 
16. Stiller KD, Schworm S. Game-Based Learning of the Structure and Functioning of Body Cells in a Foreign Language: Effects on Motivation, Cognitive Load, and Performance. Front Educ. 2019 Mar 19;4:18.

17. Randi MAF, Carvalho HF de. Learning through role-playing games: an approach for active learning and teaching. Rev Bras Educ Médica. 2013 Mar;37(1):80-8.

18. Brennan CW, Olds DM, Dolansky M, Estrada CA, Patrician PA. Learning by doing: observing an interprofessional process as an interprofessional team. J Interprof Care. 2014 May;28(3):249-51.

19. Chorazy ML, Klinedinst KS. Learn by Doing: A Model for Incorporating High-Impact Experiential Learning Into an Undergraduate Public Health Curriculum. Front Public Health. 2019 Feb 26;7:31.

20. Burgess A, Haq I, Bleasel J, et al. Team-based learning (TBL): a community of practice. BMC Med Educ. 2019 Dec;19(1):369.

21. Rotgans JI, Rajalingam P, Ferenczi MA, Low-Beer N. A Students' Model of Team-based Learning. Health Prof Educ. 2019 Dec;5(4):294-302.

22. McEwan D, Ruissen GR, Eys MA, Zumbo BD, Beauchamp MR. The Effectiveness of Teamwork Training on Teamwork Behaviors and Team Performance: A Systematic Review and Meta-Analysis of Controlled Interventions. Van Yperen NW, editor. PLOS ONE. 2017 Jan 13;12(1):e0169604.

23. Fankhauser SC, Lijek RS. Using Scavenger Hunts to Familiarize Students with Scientific Journal Articles $\uparrow$. J Microbiol Biol Educ. 2016 Mar 1;17(1):125-8.

24. Goswami B, Jain A, Koner B. Evaluation of brainstorming session as a teaching-learning tool among postgraduate medical biochemistry students. Int J Appl Basic Med Res. 2017;7(5):15.

25. Ritter SM, Mostert NM. How to facilitate a brainstorming session: The effect of idea generation techniques and of group brainstorm after individual brainstorm. Creat Ind J. 2018 Sep 2;11(3):263-77.

26. Donlan P. Use of the Online Discussion Board in Health Professions Education: Contributions, Challenges, and Considerations. J Contin Educ Health Prof. 2019;39(2):124-9.

27. Woelfle M, Olliaro P, Todd MH. Open science is a research accelerator. Nat Chem. 2011 Oct;3(10):745-8.

28. Cross D, Thomson S, Sinclair A. Research in Brazil - A report for CAPES by Clarivate Analytics [Internet]. Clarivate Analytics; 2018 p. 73. Available from: http://www.sibi.usp.br/wp-content/uploads/2018/01/Relat\%C3\%B3rio-Clarivate-CapesInCites-Brasil-2018.pdf

29. Conselho Nacional de Saúde - Comitês de Ética em Pesquisa [Internet]. Retrived 26 Mar 2021. Available from: http://conselho.saude.gov.br/comites-de-etica-em-pesquisa-conep?view=default

30. Sivarajah RT, Curci NE, Johnson EM, Lam DL, Lee JT, Richardson ML. A Review of Innovative Teaching Methods. Acad Radiol. 2019 Jan;26(1):101-13.

31. Roman C, Ellwanger J, Becker GC, Silveira AD da, Machado CLB, Manfroi WC. Metodologias Ativas De Ensino-Aprendizagem No Processo De Ensino Em Saúde No Brasil: Uma Revisão Narrativa. Clin Biomed Res. 2017;37(4):349-57.

32. Souza CDF de, Antonelli BA, Oliveira DJ de. Metodologias ativas de ensino aprendizagem na formação de profissionais da saúde. Rev Universidade Vale Rio Verde. 2016;14(2):659-77.

33. Chen T-Y. Medical leadership: An important and required competency for medical students. Tzu Chi Med J. 2018;30(2):66. 
34. Passeri SMRR, Mazur E. Peer Instruction-Based Feedback Sessions Improve the Retention of Knowledge in Medical Students. Rev Bras Educ Médica. 2019 $\mathrm{Jul} ; 43(3): 155-62$.

35. Santos VH dos, Ferreira JH, Alves GCA, et al. Currículo oculto, educação médica e profissionalismo: uma revisão integrativa. Interface - Comun Saúde Educ. 2020;24:e190572.

36. Lee Roze des Ordons A, de Groot JM, Rosenal T, Viceer N, Nixon L. How clinicians integrate humanism in their clinical workplace- 'Just trying to put myself in their human being shoes'. Perspect Med Educ. 2018 Oct;7(5):318-24.

37. Lorena SB de, Andrade M de M, Arcoverde ÂM de H, Vilela LS, Mota LRA da, Lorena Sobrinho JE de. Análise do Acesso à Informação Acadêmica entre Estudantes de Medicina Inseridos numa Metodologia Ativa de Aprendizagem. Rev Bras Educ Médica. 2019 Dec;43(4):176-86.

38. Frank JR, Snell L, Sherbino J. Royal College of Physicians and Surgeons of Canada. CanMEDS 2015: physician competency framework. 2015.

39. Future Doctor [Internet]. Health Education England. 2019. Retrived 26 Mar 2021. Available from: https://www.hee.nhs.uk/our-work/future-doctor

40. Ministério Da Educação. Resolução $\mathrm{n}^{0}$ 3, de 20 de Junho de 2014, Diretrizes curriculares nacionais do curso de graduação em medicina [Internet]. Jun 20, 2014. Available from: http://portal.mec.gov.br/index.php?option $=$ com_docman\&view $=$ download\&alias $=1587$ 4-rces003-14\&category_slug=junho-2014-pdf\&Itemid=30192

41. Griffin MF, Hindocha S. Publication practices of medical students at British medical schools: Experience, attitudes and barriers to publish. Med Teach. 2011 Jan;33(1):e1-8.

42. Patel S, Walsh CM, Udell JA. Exploring medically-related Canadian summer student research programs: a National Cross-sectional Survey Study. BMC Med Educ. 2019 Dec;19(1):140.

43. Reis Filho AJS, Andrade BB, Mendonça VRR de, Barral-Netto M. Research knowledge in undergraduate school in Brazil: a comparison between medical and law students. Einstein São Paulo. 2010 Sep;8(3):273-80.

44. Reeve C, Woolley T, Ross SJ, et al. The impact of socially-accountable health professional education: A systematic review of the literature. Med Teach. 2017 Jan 2;39(1):67-73. 